\title{
Protein methylation in cellular proliferation and differentiation: non-histone nuclear methyl acceptor protein(s) during 3'-methyl-4-dimethylaminoazobenzene- induced hepatocarcinogenesis
}

\author{
Moon-Kee Paik, ${ }^{1,4}$ Yoo-Jeong Han, ${ }^{1}$ \\ Jung-Hee Hong, ${ }^{1}$ Jung-Sook Kim, ${ }^{1}$ \\ Kwang-Sun Suh ${ }^{2}$ and Se-Jin Yoon ${ }^{1,3}$ \\ 1 Department of Biochemistry, School of Medicine, \\ Wonkwang University, Ik-San, Korea \\ 2 Department of Pathology, School of Medicine, Chungnam University, \\ Daejeon, Korea \\ 3 Department of Internal Medicine, School of Medicine, \\ Chungbook University, Chong-Ju, Korea \\ 4 Corresponding author
}

Accepted 25 January 1997
94.7\% sequence homology with human chorionic somatomammotropin precursor A and B.

Keywords: protein methyltransferases, cell division, cell differentiation, nuclear proteins, rat, dimethylaminoazobenzene, hepatoma, carcinogens

\section{Introduction}

Protein methylation is one of the posttranslational modification reactions which modulate the function of proteins. Among many protein-specific methylation reactions, enzymatic methylation of protein-arginine residues has been suggested to be involved closely in cellular growth and differentiation. These contentions are based on the following evidences. First, the enzyme S-adenosylmethionine: protein-arginine $N$-methyltransferase (protein methylase I; PM-I; EC 2.1.1.23) which is responsible for the methylation increased significantly in fast growing tissues (Tidwell et al., 1968; Lee and Paik, 1972; Paik and Kim, 1980; Wainfan et al., 1988). Secondly, many highly specialized chromosomal proteins are found to be arginine-methylated in vivo (Reporter and Corbin, 1971; Karn et al., 1977). Thirdly, an increase of PM-I activity precedes the synthesis of DNA in synchronized cell cultures (Paik and Kim, 1980; Choi, 1989). An evidence also indicated that protein-arginine $\mathrm{N}$-methylation might play a role in carcinogenesis (Yoon, 1994; Duerre et al., 1994).

Hepatocarcinogenesis has been found to be accelerated in methyl-deficient experimental animals and this effect of methyl-deficiency is attributed to insufficiency of methylation of newly formed DNA (Doerfler, 1983; Hoffman, 1985) and/or chromosomal proteins (Duerre, 1988). Obviously, chromosomal protein methylation includes arginine-methylation of non-histone chromosomal proteins. In order to elucidate biochemical function and significance of protein-arginine $N$-methylation, it appears to be imperative to identify protein species methylated under specific biological situations. Najbauer and Aswad (1990) found over $90 \%$ of the endogenous proteins were arginine $\mathrm{N}$-methylated in pheochromocytoma cells (PC 12 cell line) which were initially hypomethylated with a methylation inhibitor, followed by incubation with Ado[methyl-3H]Met. However, they did not attempt to identify the proteins involved. We recently identified a number of methyl acceptor proteins $(68,45,38,23$ and $16 \mathrm{kDa}$ ) in human placental nuclear fraction methylated 
by PM-I (Paik et al., 1991; Choi et al., 1993). Furthermore, the extents of methylation of $16-\mathrm{kDa}$ and $23 \mathrm{kDa}$ proteins were very different in opposing manner during hepatic regeneration of rat. It was suggested that methylation of the $16 \mathrm{kDa}$ protein might be involved in cellular growth whereas that of the $23 \mathrm{kDa}$ in cellular differentiation (Lee et al., 1994).

In the present study, we fed rats with methyl deficient diet (MDD), and confirmed that the induction of cholangiocarcinoma by 3'-methyl-4-dimethylaminoazobenzene (MeDAB) was accelerated in these animals. During the induction, however, the $23-\mathrm{kDa}$ protein methylation was lost. The amino acid sequence analysis of $\mathrm{N}$-terminal 20 amino acids showed $94.7 \%$ sequence homology with human chorionic somatomammotropin.

\section{Materials and Methods}

\section{Materials}

S-Adenosyl-L-[methyl- $\left.{ }^{14} \mathrm{C}\right]$ methionine (specific activity, $49 \mathrm{mCi} / \mathrm{mmol})$ and S-adenosyl-L-[methyl- $\left.{ }^{3} \mathrm{H}\right]$ methionine (specific activity, $73 \mathrm{Ci} / \mathrm{mmol}$ ) were purchased from Amersham International. Acrylamide, glycine, hydroxyapatite, and PVDF protein sequence membrane were obtained from Bio-Rad Laboratories, and DEAE-Sephacel from Pharmacia. Histone type II-AS (a mixture of various subtypes of calf thymus histone), histone $\mathrm{H} 2 \mathrm{~A}$, histone $\mathrm{H} 3$, dithiothreitol, phenylmethylsulfonyl fluoride (PMSF), trizma base and 2,5-diphenyloxazole were from Sigma Chemical Co. MDD and control synthetic diet (CSD) were prepared by Harlan Teklad, Wisconsin, and 3'-4-dimethylaminoazobenzene from Tokyo Whasei Co., Japan. The rest of the reagents were obtained from various commercial sources and of the highest purity available.

Table 1. The composition of diets (per $\mathrm{kg}$ )

\begin{tabular}{lcc}
\hline \multirow{2}{*}{ Constituents } & \multicolumn{2}{c}{ Diet } \\
\cline { 2 - 3 } & Control & MDD \\
\hline Amino acid mixture & $180 \mathrm{~g}$ & $180 \mathrm{~g}$ \\
Corn oil & $50 \mathrm{~g}$ & $50 \mathrm{~g}$ \\
Glucose monohydrate & $770 \mathrm{~g}$ & $770 \mathrm{~g}$ \\
Salt mixture & $40 \mathrm{~g}$ & $40 \mathrm{~g}$ \\
Riboflavin & $0.001 \mathrm{~g}$ & $0.001 \mathrm{~g}$ \\
Vitamin mixture $^{\mathrm{a}}$ & $5 \mathrm{ml}$ & $5 \mathrm{ml}$ \\
MeDAB & $0.7 \mathrm{~g}$ & $0.7 \mathrm{~g}$ \\
\hline
\end{tabular}

a Contains cod liver oil $20 \mathrm{~g}$, choline chloride $1.5 \mathrm{~g}$ and pteroylglutamic acid $0.6 \mathrm{~g}$, biotin $1.5 \mathrm{mg}$, thiamine $-\mathrm{HCl} 20 \mathrm{mg}$, pyridoxine- $\mathrm{HCl} 20 \mathrm{mg}$, menadione $50 \mathrm{mg}$ (in $20 \mathrm{~g}$ of cod liver oil), nicotinamide $50 \mathrm{mg}$, potassium parabenzoate $50 \mathrm{mg}$, calcium pantothenic acid $60 \mathrm{mg}$, inositol $10 \mathrm{mg}$ and cyanocobalamin $40 \mu \mathrm{g}$.

\section{Experimental animals}

Sprague-Dawley rats, weighing approximately $150 \mathrm{~g}$, were fed for 2 weeks with normal diet before the start of experiments. After acclimatization, the animals were divided into MDD alone, CSD+0.07\% MeDAB, and MDD $+0.07 \%$ MeDAB groups, and the animals were fed with the diets for 12 weeks. MeDAB was dissolved in corn oil. The composition of the diets are listed in Table 1.

\section{Enzyme assay}

Protein methylase I activity was assayed according to the method of Paik and Kim (1980). Incubation mixture containing $100 \mu \mathrm{l}$ of $0.2 \mathrm{M}$ phosphate buffer ( $\mathrm{pH} 7.6), 50$ $\mu \mathrm{l}$ of histone II-AS $(40 \mathrm{mg} / \mathrm{ml})$ and $50 \mu \mathrm{l}$ of enzyme preparation was preincubated at $37^{\circ} \mathrm{C}$ for $3 \mathrm{~min}$, followed by the addition of $20 \mu \mathrm{l}$ of Ado[methyl- $\left.{ }^{14} \mathrm{C}\right] \mathrm{Met}(2.5 \mathrm{nmol}$, $0.125 \mu \mathrm{Ci}$ ). Incubation was carried out for $30 \mathrm{~min}$ at $37^{\circ} \mathrm{C}$. The enzyme preparation boiled for $5 \mathrm{~min}$ served as a blank for the enzyme. The reaction was terminated by adding $4 \mathrm{ml}$ of $15 \%$ trichloroacetic acid to the mixture. Unreacted Ado[methyl- $\left.{ }^{14} \mathrm{C}\right]$ Met, nucleic acid, phospholipid and the product formed by contaminating protein methylase II (S-adenosyl-methionine: protein carboxyl O-methyltransferase; EC 2.1.1.24) were removed, and the final precipitate was dissolved in $10 \mathrm{ml}$ of liquid scintillation fluid for radioactivity counting.

Protein concentration was estimated by the method of Bradford (1976), using bovine serum albumin as the standard.

\section{Partial purification of protein methylase I}

All the procedures were carried out at $4^{\circ} \mathrm{C}$. Ten $\mathrm{g}$ of liver from MDD+MeDAB fed rats or normal rats was homogenized in $40 \mathrm{ml}$ of buffer $A$ containing $0.5 \mathrm{mM}$ EDTA, $0.5 \mathrm{mM}$ PMSF, $1 \mathrm{mM}$ dithiothreitol, $5 \mathrm{mM} \mathrm{NH}_{4} \mathrm{Cl}$, $10 \%$ glycerol, $5 \mathrm{mM}$ phosphate buffer $(\mathrm{pH} 7.4)$ by polytron Brinkman homogenizer for $10 \mathrm{~s}$ five times. The homogenate was centrifuged at $39,000 \mathrm{~g}$ for $30 \mathrm{~min}$ and finely powdered $\left(\mathrm{NH}_{4}\right)_{2} \mathrm{SO}_{4}$ was added to the supernatant at $58 \%$ saturation. The mixture was left in ice-bath for $30 \mathrm{~min}$ and then centrifuged at $39,000 \mathrm{~g}$ for $30 \mathrm{~min}$. The precipitate was dissolved in $7 \mathrm{ml}$ of buffer $\mathrm{A}(\mathrm{pH}$ 8.0), and $\left(\mathrm{NH}_{4}\right)_{2} \mathrm{SO}_{4}$ was added at $55 \%$ saturation. The enzyme preparation was dialyzed against buffer $\mathrm{A}(\mathrm{pH}$ 8.0), the volume was made up to $50 \mathrm{ml}$, and the sample was loaded onto DEAE-Sephacel chromatography column $(1.4 \times 4.5 \mathrm{~cm}$; packing volume, $7 \mathrm{ml})$ which had been equilibrated with buffer $A$. The column was washed with $50 \mathrm{mM}$ buffer $\mathrm{A}(\mathrm{pH} 8.0)$ until no $280 \mathrm{~nm}$ absorbing material was detected. The column was eluted with a linear gradient formed by $35 \mathrm{ml}$ each of buffer $\mathrm{A}(\mathrm{pH} 8.0)$ containing 0 and $500 \mathrm{mM} \mathrm{NaCl}$. Fraction volume was 50 drops $(2.5 \mathrm{ml})$. The enzyme activity was detected in fractions 7 to 14 , and the contents of fraction 8 through 12 were pooled (Figure 
1). The pooled sample was made to $60 \%\left(\mathrm{NH}_{4}\right)_{2} \mathrm{SO}_{4}$, dialyzed against buffer $\mathrm{A}(\mathrm{pH} 8.0)$, and the volume was made to $30 \mathrm{ml}$. The sample was subsequently loaded onto hydroxyapatite column $(0.7 \times 2.5 \mathrm{~cm}$; packing volume, $1 \mathrm{ml}$ ) which had been equilibrated with buffer $A$. The column was eluted with a linear gradient formed by $10 \mathrm{ml}$ each of buffer A containing $5 \mathrm{mM}$ and $300 \mathrm{mM}$ phosphate. Fraction volume was 20 drops $(1 \mathrm{ml})$, and the enzyme activity was detected in fractions 5 through 10 (Figure 2). The samples of fraction 6 and 7 were pooled and were used throughout this experiment. Protein concentration was $2.6 \mathrm{mg} / \mathrm{ml}$.

\section{Preparation of liver nuclear fraction}

Rat liver nuclear fraction was prepared according to the method of Kay and Johnson (1977). Approximately $30 \mathrm{~g}$ of rat liver was homogenized in 3 times volume of 10 $\mathrm{mM}$ Tris- $\mathrm{HCl}$ buffer ( $\mathrm{pH} 7.4$ ) containing $0.32 \mathrm{M}$ sucrose, $3 \mathrm{mM} \mathrm{MgCl}_{2}, 0.5 \mathrm{mM} \mathrm{PMSF}$, and the homogenate was centrifuged at $700 \mathrm{~g}$ for $10 \mathrm{~min}$. The pellet obtained was resuspended in the above sucrose solution and was centrifuged again at $700 \mathrm{~g}$ for $10 \mathrm{~min}$. The crude nuclear fraction thus obtained was suspended in $2.4 \mathrm{M}$ sucrose, $1 \mathrm{mM} \mathrm{MgCl}$, $0.5 \mathrm{mM}$ PMSF, $10 \mathrm{mM}$ Tris buffer (pH 7.4), and the suspension was centrifuged at 50,000 $g$ for $60 \mathrm{~min}$. The precipitate was suspended in $0.25 \mathrm{M}$ sucrose, $1 \mathrm{mM} \mathrm{MgCl}_{2}, 0.5 \mathrm{mM}$ PMSF, $10 \mathrm{mM}$ Tris buffer (pH 7.4), and the suspension was finally centrifuged at $700 \mathrm{~g}$ for $10 \mathrm{~min}$ to obtain a nuclear fraction.

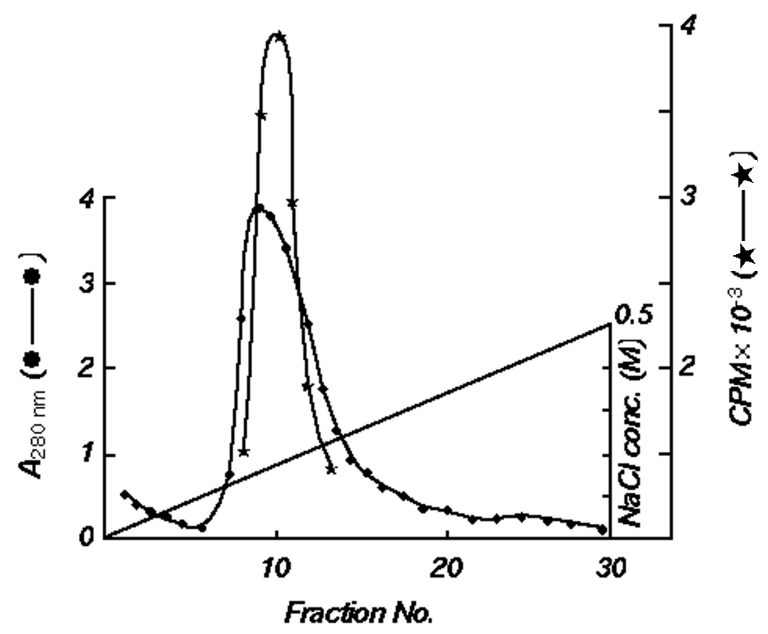

Figure 1 DEAE-Sephacel chromatography of protein methylase I of MDD+MeDAB treated rat liver. Ammonium sulfate treated preparation was applied to DEAE-Sephacel column $(1.4 \times 4.5 \mathrm{~cm}$; packing volume, $7 \mathrm{ml})$ equilibrated previously with $5 \mathrm{mM}$ phosphate buffer(pH 8.0) containing $1 \mathrm{mM}$ DTT, $0.5 \mathrm{mM}$ EDTA, $0.5 \mathrm{mM}$ PMSF, $5 \mathrm{mM}$ $\mathrm{NH}_{4} \mathrm{Cl}, 10 \%$ glycerol. Flow rate was $24 \mathrm{ml} / \mathrm{h}$ and $2.5 \mathrm{ml}(50$ drops $)$ of eluate was collected. represents $A 280 \mathrm{~nm}$ and $\star$ for enzyme activity. An assay was performed as described under "Materials and Methods".

\section{SDS-PAGE and autofluorography of methyl- ${ }^{3} \mathrm{H}-$ labeled proteins}

In order to identify methyl- ${ }^{3} \mathrm{H}$-labeled proteins methylated by $\mathrm{PM}-\mathrm{I}$ of normal and MDD+MeDAB-treated rat livers, $200 \mu$ of total incubation mixture containing PM-I, substrate proteins (liver nuclear fraction), Ado[methyl${ }^{3} \mathrm{H}$ ]Met $(0.125 \mathrm{nmol}, 20 \mu \mathrm{Ci})$ and $15 \mu \mathrm{mol}$ of phosphate buffer $(\mathrm{pH} 7.8)$ was incubated at $37^{\circ} \mathrm{C}$ for $1 \mathrm{~h}$. Precipitate formed by adding enough amount of absolute ethanol was collected by centrifugation, the precipitate air-dried, and the dried sample dissolved in $2 \%$ SDS, 5\% 2mercaptoethanol, $10 \%$ glycerol, $0.002 \%$ bromophenol blue, $62 \mathrm{mM}$ Tris buffer ( $\mathrm{pH}$ 6.8). The sample was electrophoresed (SDS-PAGE), followed by autofluorography according to the method of Thomas and Kornberg (1977) modified from the method of Laemmli (1970). Electrophoresis was carried out at $40 \mathrm{~mA}$ for $12 \mathrm{~h}$, the gels were stained by $0.1 \%$ Coomassie brilliant blue, and were destained with $50 \%$ methanol, $10 \%$ acetic acid. For autofluorography, the destained gels were soaked in dimethylsulfoxide containing $20 \%$ 2,5-diphenyloxazole for $1 \mathrm{~h}$. After drying, the gels were exposed to Fuji medical $\mathrm{X}$-ray films for $2-7$ days at $-70^{\circ} \mathrm{C}$.

\section{Isolation of nuclear membrane}

Preparation of liver nuclear membrane was carried out at $4^{\circ} \mathrm{C}$ by the method of Kaufmann et al. (1982). The purified nuclei were suspended at $3-5 \times 10^{8}$ nuclei $/ \mathrm{ml}$ in

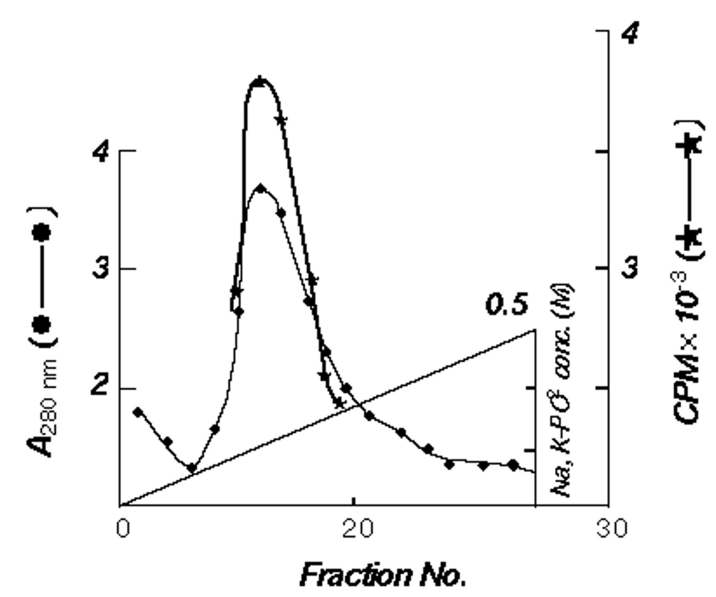

Figure 2. Hydroxyapatite chromatography of protein methylase I of MDD+MeDAB treated rat liver. DEAE-Sephacel chromatography fractions were applied onto hydroxyapatite column $(0.7 \times 2.5 \mathrm{~cm}$; packing volume, $1 \mathrm{ml})$ equilibrated previously with $5 \mathrm{mM}$ phosphate buffer(pH 8.0) containing $1 \mathrm{mM}$ DTT, $0.5 \mathrm{mM}$ EDTA, $0.5 \mathrm{mM}$ PMSF, 5 $\mathrm{mM} \mathrm{NH}_{4} \mathrm{Cl}, 10 \%$ glycerol. Flow rate was $12 \mathrm{ml} / \mathrm{h}$ and $1 \mathrm{ml}(20$ drops) of eluate was collected. represents A280 nm and $\star$ for enzyme activity. An assay was performed as described under "Materials and Methods". 
$0.25 \mathrm{M}$ sucrose, $5 \mathrm{mM} \mathrm{MgCl}_{2}, 50 \mathrm{mM}$ Tris $(\mathrm{pH} 7.4$ at $4^{\circ} \mathrm{C}$ ) (called STM in the following), and the suspension was treated with DNAse $(250 \mu \mathrm{g} / \mathrm{ml})$ and RNAse I (250 $\mu \mathrm{g} / \mathrm{ml})$ at $4^{\circ} \mathrm{C}$ for $1 \mathrm{~h}$. The suspension was then centrifuged at $800 \mathrm{~g}$ for $10 \mathrm{~min}$. The pellet was suspended in $10 \mathrm{mM}$ Tris buffer ( $\mathrm{pH} 7.4$ ), $0.2 \mathrm{mM} \mathrm{MgSO}_{4}$ followed by drop-wise addition of the buffer containing $2 \mathrm{M} \mathrm{NaCl}$, and 2-mercaptoethanol to the suspension to $1 \%$ final concentration while stirring. The mixture was incubated at $4^{\circ} \mathrm{C}$ for $15 \mathrm{~min}$, and the precipitate was collected by centrifugation at $1,600 \mathrm{~g}$ for $30 \mathrm{~min}$. The procedure was repeated once more with the above buffer which did not contain 2-mercaptoethanol. Finally, the precipitate was dissolved in $0.25 \mathrm{M}$ sucrose, $5 \mathrm{mM} \mathrm{MgCl}_{2}-50 \mathrm{mM}$ Tris buffer ( $\mathrm{pH}$ 7.4).

\section{Purification of 23-kDa protein}

The rat liver nuclear membrane $(8.5 \mathrm{mg})$ isolated above was methylated by purified PM-I in the presence of Ado $\left[\right.$ methyl- $\left.{ }^{3} \mathrm{H}\right] \mathrm{Met}$, and methyl- ${ }^{3} \mathrm{H}$-labeled $23-\mathrm{kDa}$ protein was obtained by a preparatory gel elctrophoresis (Prep-Cell, Bio-Rad Model 491) (Laemmli, 1970).

Thus, methyl- ${ }^{3} \mathrm{H}$-labeled nuclear envelope $(0.85 \mathrm{mg})$ was suspended in the sample buffer containing $2.5 \%$ glycerol, $0.5 \%$ SDS, $0.005 \%$ bromophenol blue, the sample was loaded for SDS-polyacrylamide gel, and preparatory electrophoresis was performed at 12 watt for $6 \mathrm{~h}$. Two and half $\mathrm{ml}$ of each fractions were collected at the rate of $1 \mathrm{ml} / \mathrm{min}$. With the use of SDS-PAGE and fluorography, the 23-kDa protein was identified and fractions containing 23-kDa protein (fraction No. 72-75) were pooled. The pooled sample was concentrated by Speed-Vac and Centricon 10, electrophoresed, and transferred to PVDF membrane by the use of Wet-Blotter (Sigma). For transblotting, Towbin buffer was employed at 30 volts for $12 \mathrm{~h}$. PVDF membrane containing the 23$\mathrm{kDa}$ protein was sent to Korean Science Foundation for amino acid sequence analysis.

\section{Results}

\section{Comparison of carcinogenesis of CSD+MeDAB and MDD+MeDAB rats}

In order to study the effect of methyl deficient state on carcinogenesis, animals were fed CSD plus MeDAB and MDD plus MeDAB diets. During hepatocarcinogenesis, oval cell proliferation, hyperplastic nodule, cholangiofibrosis and cholangiocarcinoma were examined. As shown in Table 2, CSD+MeDAB treatment resulted in proliferation of oval cells at 2 weeks, and proliferation increased greatly at 8 weeks. Cholagiocarcinoma appeared on 10 weeks of treatment. In contrast to the above, MDD+MeDAB treated rats showed cholangiocarcinoma 2-4 weeks earlier than the CSD+MeDAB group, and steatosis (fatty change) much earlier than CSD+MeDAB-treated rats (Table 3 and Figure 3-5). It is also noted that the change occurred much more widely.

\section{Change of protein methylase I activity by MDD}

As shown in Table 4, protein methylase I activity began to increase at about 2 weeks of MDD-feeding, reaching

Table 2. Histopathologic features during CSD+MeDAB induced hepatocacinogenesis. Experimental details are described under "Materials and Methods".

\begin{tabular}{llllllllll}
\hline \multirow{2}{*}{ Pathology } & \multicolumn{7}{c}{ Duration } & of CSD+MeDAB Treatment (weeks) \\
\cline { 2 - 8 } & 0 & 2 & 4 & 6 & 8 & 10 & 12 & 14 \\
\hline Oval cell Proliferation & - & + & + & + & +++ & +++ & ++ & +++ \\
Hyperplastic Nodule (atypia) & - & - & + & + & +++ & +++ & +++ & +++ \\
Cholangiofibrosis (atypia) & - & - & + & + & +++ & +++ & ++ & +++ \\
Cholangiocarcinoma & - & - & - & - & - & + & + & + \\
Steatosis (fatty change) & - & - & - & - & - & - & - & - \\
\hline
\end{tabular}

Table 3. Histopathologic features during MDD+MeDAB induced hepatocacinogenesis. Experimental details are described under "Materials and Methods".

\begin{tabular}{lccccccccc}
\hline \multirow{2}{*}{ Pathology } & \multicolumn{7}{c}{ Duration of CSD+MeDAB } & Treatment (weeks) \\
\cline { 2 - 8 } & 0 & 2 & 4 & 6 & 8 & 10 & 12 & 14 \\
\hline Oval cell Proliferation & - & + & + & +++ & +++ & ++ & +++ & +++ \\
Hyperplastic Nodule (atypia) & - & - & - & ++ & + & +++ & +++ & +++ \\
Cholangiofibrosis (atypia) & - & - & ++ & ++ & +++ & ++ & +++ & +++ \\
Cholangiocarcinoma & - & - & - & - & + & + & + & + \\
Steatosis (fatty change) & ++ & + & + & + & + & + & + & + \\
\hline
\end{tabular}



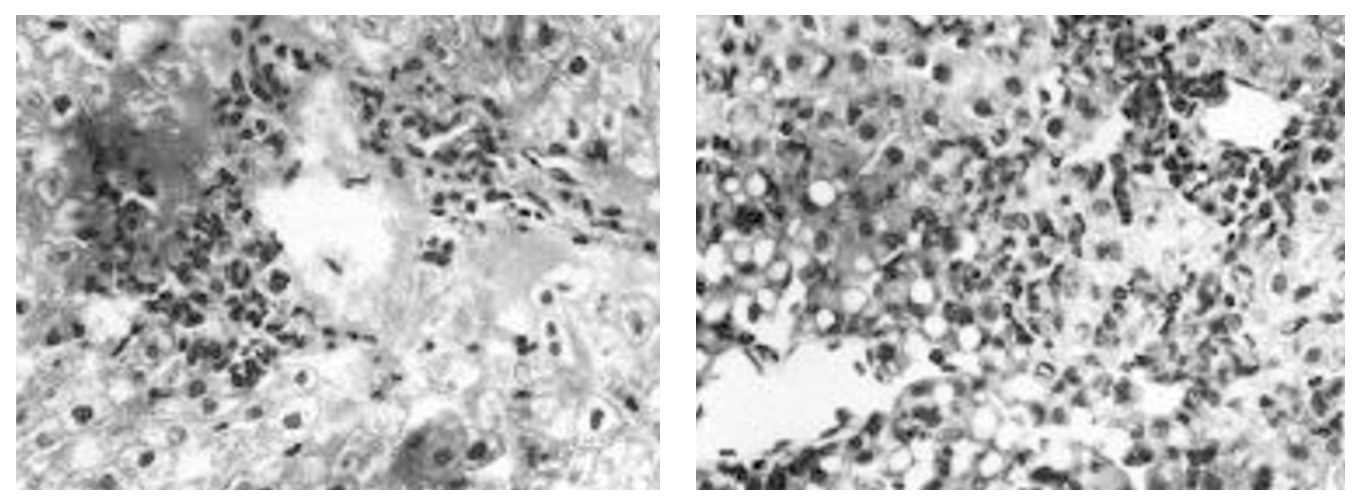

Figure 3. At 2 weeks after MeDAB treatment, CSD group(a) showed only a few small basophilic cells in and around the portal tracks, while MDD group(b) had prominent oval cell proliferation, some of which are organized into ductlike structures. Some of the hepatocytes showed macrovesicular steatosis (H\&E, X400).
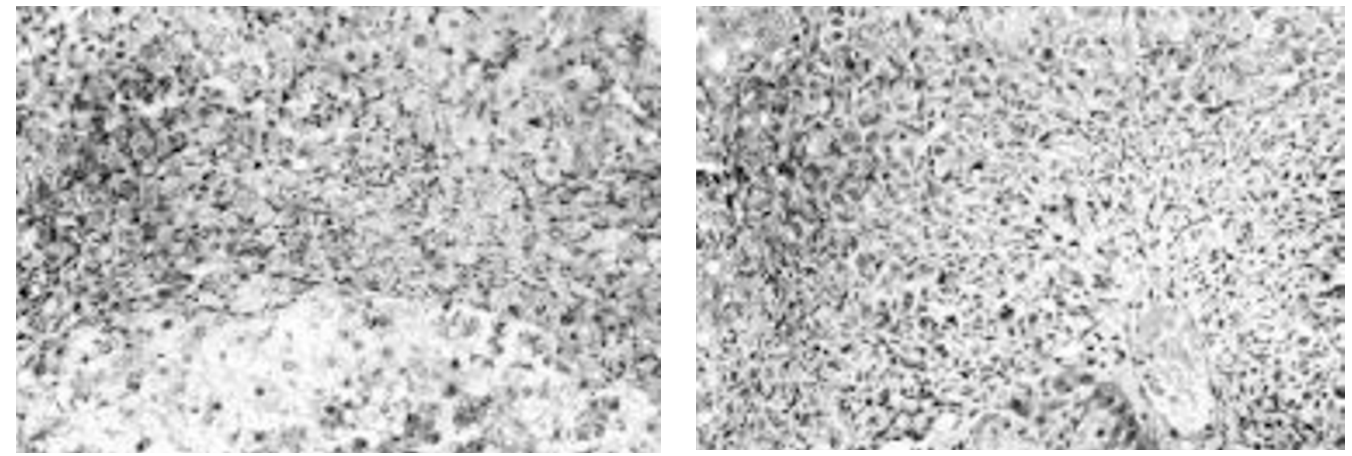

Figure 4. At 6 weeks, hyperplastic nodules were produced in CSD group(a), accompanied by marked proliferation of oval cells. In addition, cholangiofibrosis was also seen. In MDD group(b), marked proliferation of oval cells occupying more than one-half of the liver lobule was characteristic (H\&E, X200).
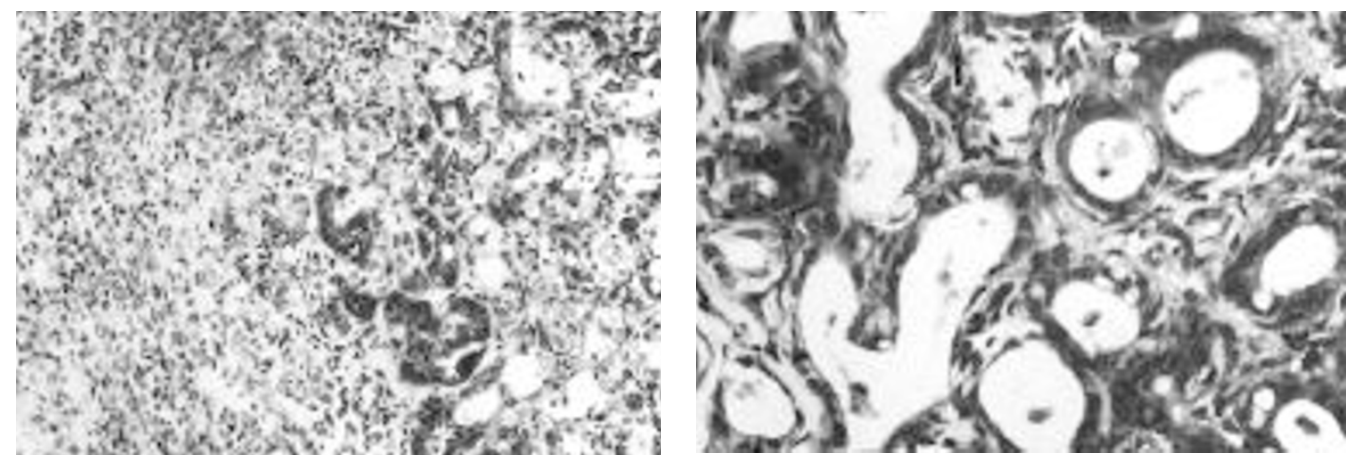

Figure 5. At 8 weeks, cholangiocarcinoma was identified in MDD group(a) (H\&E, x400). In CSD group, cholangiocarcinoma was seen at 10 weeks(b) (H\&E, x200).

about $50 \%$ increase at 4 weeks and declining thereafter. However, considerably high enzyme activity was maintained even after 8 weeks of the experiment.

\section{Purification of protein methylase I}

Protein methylase I has been partially purified from the livers of CSD-fed, MDD-fed and MDD+MeDAB-fed rats up to DEAE-Sephacel and hydroxyapatite column chromatography. Although there was not much difference in the procedures among these livers, the purification procedure of the liver of MDD+MeDAB treated rat is presented in Figures 1, 2 and Table 5. Thus, the enzyme
Table 4. Changes of PM I activity by MDD feeding. Experimental details are described in the text. These values are the average of at least two independent determination.

\begin{tabular}{lccc}
\hline Weeks & Protein $(\mathrm{mg} / \mathrm{ml})$ & Specific activity & Activity $(\%)$ \\
\hline Control & 19.0 & 0.29 & 100 \\
2 & 21.3 & 0.32 & 121 \\
4 & 19.8 & 0.46 & 162 \\
6 & 21.7 & 0.36 & 139 \\
8 & 20.4 & 0.36 & 129 \\
\hline
\end{tabular}


Table 5. Purification of protein methylase I from MDD+MeDAB treated rat liver. Experimental details are described under "Materials and Methods".

\begin{tabular}{|c|c|c|c|c|c|}
\hline \multirow{2}{*}{ Purification steps } & \multirow{2}{*}{$\begin{array}{l}\begin{array}{l}\text { Total } \\
\text { protein }\end{array} \\
(\mathrm{mg})\end{array}$} & \multicolumn{2}{|c|}{ Enzyme Activity } & \multicolumn{2}{|c|}{ Purification } \\
\hline & & $\begin{array}{c}\text { Specific } \\
\text { (pmol/mg/min) }\end{array}$ & $\begin{array}{c}\text { Total } \\
(\mathrm{pmol} / \mathrm{min})\end{array}$ & Fold & $\begin{array}{r}\text { Yield } \\
(\%)\end{array}$ \\
\hline $\begin{array}{l}\text { Supernatant at } \\
39,000 \mathrm{~g}\end{array}$ & 475 & 0.16 & 76 & 1 & 100 \\
\hline $\begin{array}{l}\left(\mathrm{NH}_{4}\right)_{2} \mathrm{SO}_{4} \text { Precip. } \\
\text { at } 0-55 \% \text { saturation }\end{array}$ & 228 & 0.48 & 110 & 3 & 140 \\
\hline $\begin{array}{l}\text { DEAE-Sephacel } \\
\text { chromatography }\end{array}$ & 25 & 3.8 & 96 & 23 & 120 \\
\hline $\begin{array}{l}\text { Hydroxyapatite } \\
\text { chromatography }\end{array}$ & 5.2 & 4.3 & 23 & 27 & 30 \\
\hline
\end{tabular}

purified from this source was routinely employed in the following experiment. As shown in Table 5, the enzyme was purified approximately 27 -fold with a yield of $30 \%$ from MDD+MeDAB rat liver.

\section{Methylation of 16-kDa and 23-kDa proteins}

In order to investigate which nuclear proteins are methylated during accelerated induction of cholangiocarcinoma by methyl-deficient state, the PM-ls purified from both normal and MDD+MeDAB treated rat livers were incubated with nuclei isolated from normal and MDD+MeDAB livers in the presence of Ado[methyl$\left.{ }^{3} \mathrm{H}\right] \mathrm{Met}$, and methyl- ${ }^{3} \mathrm{H}$-labeled proteins were identified by SDS-PAGE and autofluorography (Figures 6-7). In Figure 6, nuclei (here, used as substrate for methylation) were isolated from $C S D+M e D A B$ treated rat liver while PM-I was from normal liver. The numbers 2, 4, 6, $8,10,12$ and 14 represent $2,4,6,8,10,12$ and 14 weeks of treatment. It is apparent that methylation of 16- and $23-\mathrm{kDa}$ proteins are very prominent and that the longer the treatment the stronger the intensity of methylation. On the other hand, as seen in Figure 7, when both $P M-I$ and nuclei were isolated from CSD+MeDAB treated rat liver, the methylation of 23$\mathrm{kDa}$ protein is not present although the methylation of 16-kDa protein remained the same as in Figure 6. Since nuclei used in both Figures 6 and 7 were isolated from the same source and PM-I came from differently treated animals, the loss of $23-\mathrm{kDa}$ methylation is due to the fact that PM-I responsible for methylation of 23$\mathrm{kDa}$ protein was lost in MeDAB-treatment.

\section{Sequence of $\mathbf{N}$-terminal 20 amino acid of 23 kDa protein}

The 23-kDa protein was purified by Prep-Cell (Bio-Rad) after methylating isolated nuclei with purified PM-I of normal rat liver. The sequence of 20 terminal amino acids were ${ }^{1}$ Gly-Val-Pro-Leu- ${ }^{5}$ X-Arg- Leu-Phe-Asp-
Table 6. N-terminal amino acid sequence of 23-kDa nuclear methyl acceptor protein. $\stackrel{1}{\text { Gly-Val-Pro-Leu-X-Arg-Leu-Phe-Asp-His-Ala-Met-Leu-Gln- }_{2}^{5}}$ 1520

Ala-His-Arg-Ala-His-Gln

23kDa protein $\quad \stackrel{1}{\text { GVPLXRLFDHAMLQAHRAHQ }}$

Choriomammotropin $\stackrel{1}{\text { TVPLSRLFDHAMLQAHRAHQ }}$

\begin{tabular}{ll}
\hline Protein & Match \% \\
\hline Choriomammotropin & \\
B precursor (human) & 94.7 \\
A precursor (human) & 94.7 \\
Somatotropin & \\
$\quad$ Precursor (human) & 68.4 \\
$\quad$ Precursor (rat) & 45.0 \\
Growth hormone & \\
Variant (placenta) & 66.7 \\
\hline
\end{tabular}

${ }^{10} \mathrm{His}-\mathrm{Ala}-\mathrm{Met}-\mathrm{Leu}-\mathrm{Gln}-{ }^{15} \mathrm{Ala}-\mathrm{His}-\mathrm{Arg}-\mathrm{Ala}-\mathrm{His}-{ }^{20} \mathrm{GIn}$. From the search of Data-Bank, this sequence was found to have $94.7 \%$ homology with human chorionic somatomammotropin (Table 6). Although the identity of the fifth amino acid is not known, this is most likely $\mathrm{N}$ methylated arginine.

\section{Discussion}

When a hepatocarcinogen L-ethionine was given to partially hepatectomized rats, methylation of histone and non-histone chromosomal proteins was found to be greatly reduced, although their synthesis was not affected 


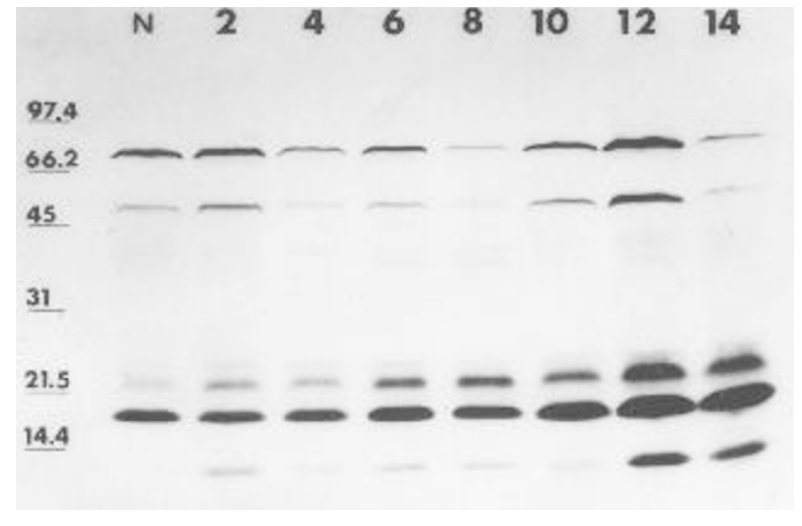

Figure 6. Analysis of methyl- ${ }^{3} \mathrm{H}$-labeled proteins by SDS-polyacrylamide gel electrophoresis and autofluorography. Nuclei isolated from rat liver were incubated with the purified protein methylase I (PM I) from normal liver and S-adenosyl-L-[methyl$\left.{ }^{3} \mathrm{H}\right]$ methionine for 1 hour, subsequently electrophoresed on $18 \%$ SDS-PAGE followed by autofluorographic analysis. $N$ indicates normal nuclei and 2, 4, 6, 8, 10, 12, 14 indicate nuclei isolated from CSD+MeDAB treated liver for 2weeks, 4weeks, 6weeks, 8 weeks, 10weeks, 12weeks, 14weeks, respectively. Molecular weight markers [lysozyme(14.4 kDa), trypsin inhibitor $(21.5 \mathrm{kDa})$, carbonyl anhydrase $(31 \mathrm{kDa})$, ovalbumin $(45 \mathrm{kDa})$, bovine serum albumin $(66.2 \mathrm{kDa})$, phosphorylase $\mathrm{b}(97.4 \mathrm{kDa})]$ were also run. More detailed experimental conditions were described under "Materials and Methods".

(Cox and Tuck, 1981; Tuck and Cox, 1982). The results suggest that methylation of these proteins are involved in induction of cancer. Furthermore, the methylation of non-histone chromosomal proteins was much more reduced than histone on L-ethionine administration (Cox and Tuck, 1981; Tuck and Cox, 1982). It is well known that histones which constitute nucleosome structure is lysine $\mathrm{N}$-methylated whereas non-histone chromosomal proteins are arginine $\mathrm{N}$-methylated (Duerre and Onisk, 1985; Duerre et al, 1990), suggesting that methylation of non-histone chromosomal proteins observed during carcinogenesis is arginine $N$ methylation.

Yoon (1994) recently reported that arginine $N$ methylation of $23-\mathrm{kDa}$ nuclear protein might be involved in the induction of cancer by MeDAB. The present results confirmed the observation of Yoon that 23-kDa protein arginine methylation might indeed be involved in the accelerating effect of MDD in cancer induction. When PM-I of normal liver was incubated with nuclei of normal liver with Ado[methyl- $\left.{ }^{3} \mathrm{H}\right] \mathrm{Met}, 16-$ and 23-kDa proteins were heavily methylated (Figure $6)$. The degree of methylation seemed to increase as the tumorigenesis progressed. On the other hand, when PM-I of cancer tissue was reacted with nuclei of both normal or cancerous tissues, the methylation of 23$\mathrm{kDa}$ protein was not visible, although the methylation of $16-\mathrm{kDa}$ remained undiminished. This result shows a

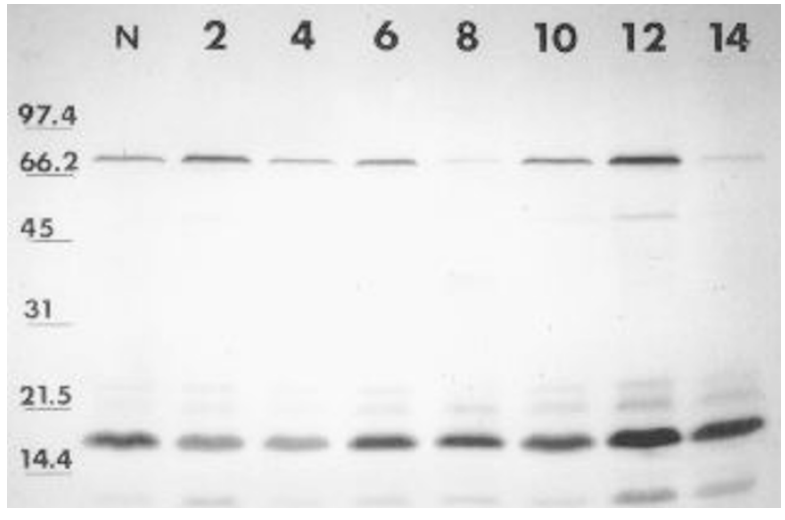

Figure 7. Analysis of methyl- ${ }^{3} \mathrm{H}$-labeled proteins by SDS-polyacrylamide gel electrophoresis and autofluorography. Nuclei isolated from rat liver were incubated with the purified protein methylase I (PM I) from CSD+MeDAB treated liver and S-adenosylL-[methyl- $\left.{ }^{3} \mathrm{H}\right]$ methionine for 1 hour, subsequently electrophoresed on 18\% SDS-PAGE followed by autofluorographic analysis. $N$ indicates normal nuclei and 2, 4, 6, 8, 10, 12 14 , indicate nuclei isolated from CSD+MeDAB treated liver for 2 weeks, 4weeks, 6 weeks, 8weeks, 10weeks, 12weeks, 14weeks, respectively. Molecular weight markers [lysozyme(14.4 kDa), trypsin inhibitor(21.5 kDa), carbonyl anhydrase(31 kDa), ovalbumin $(45 \mathrm{kDa})$, bovine serum albumin $(66.2 \mathrm{kDa})$, phosphorylase $\mathrm{b}(97.4 \mathrm{kDa})]$ were also run. More detailed experimental conditions were described under "Materials and Methods".

close relationship between the induction of cancer and methylation of 23-kDa protein, and agrees well with the result of Yoon (1994).

The loss of 23-kDa protein methylation(Figures 6-7) is due to the loss of $23 \mathrm{kDa}$-protein specific protein methylase I. There exist a few different subtypes of protein methylase I (Paik and Kim, 1990). For example, myelin basic protein specific PM-I methylates myelin basic protein only, and heterogenous nuclear ribonucleoprotein particle protein A1 (protein A1)-specific PM-I methylates both histones and protein A1 (Rajpurohit et al., 1994). These two subtypes of protein methylase I have been distinguished in their molecular weights, affinities for protein substrates, and immunological recognition. It is, therefore, suggested that PM-I not only recognizes potential methylatable arginine residues, but also protein structure. As shown in Figures 6 and 7, evidence indicates a presence of $23 \mathrm{kDa}$-protein specific $\mathrm{PM}-\mathrm{I}$ which is lost during carcinogenesis.

We have earlier suggested that methylation of 16and 23-kDa nuclear proteins are involved in cellular growth and differentiation. During hepatic regeneration of rats, changing patterns of $16-$ and $23-\mathrm{kDa}$ protein methylation were quite different in opposing manner: While $16-k D a$ protein methylation increased as the growth progressed, 23-kDa protein methylation was not seen first and reappeared as the growth slowed down (Lee at al., 1994). Involvement of 16- and 23-kDa 
nuclear protein methylation in cellular growth and differentiation was also observed in human placenta (Paik et al., 1991; Choi et al., 1992). While methylation of both 16- and 23-kDa proteins occurred in human placenta during the early stage of pregnancy when DNA synthesis was high, only $23-k D a$ protein methylation was observed in the later stage placenta when only protein synthesis occurred in the differentiated state. Thus, the loss of 23-kDa protein methylation in MDD+MeDAB treated rats could mostly be due to the loss of 23-kDa protein-specific protein methylase I. Since it has been well known that methyl deficiency accelerates cellular growth (Abanobi et al., 1982), the enzymatic methylation of both 16- and 23$\mathrm{kDa}$ nuclear proteins might be heavily involved in carcinogenesis.

The sequence of $N$-terminal 20 amino acids of 23$\mathrm{kDa}$ nuclear protein purified from nuclear membrane had $94.7 \%$ homology with human placental somatomammotropin (precursors A and B), suggesting the identity of $23-\mathrm{kDa}$ protein with human chorionic somatomammotropin. However, a few unsettling questions exist. First, this hormone is produced by placenta and presents in the cytosol, whereas $23-\mathrm{kDa}$ protein was isolated from nuclei. Secondary, the 23-kDa protein methylation varied during hepatic regeneration. Since the biochemical function of somatomammotropin is not well understood, the biological significance of this protein (the 23-kDa protein and/or somatomammotropin) is not clear at present.

\section{Acknowledgements}

This work was supported in part by Basic Medical Research Fund (1995), Ministry of Education, Korea.

\section{References}

Abanobi, S. E., Lombardi, B. and Shinozuka, H. (1982) Stimulation of DNA synthesis and cell proliferation in the liver of rats fed a choline-devoid diet and their suppression by phenobarbital. Cancer Res. 42: 412-415

Bradford, M. M. (1976) A rapid and sensitive methode for the quantita-tion of microgram quantities of protein utilizing the principle of protein-dye binding. Anal. Biochem. 72: 248-254

Cox, R. and Tuck, M. T. (1981) Alteration of methylation patterns in rat histones following administration of ethionine, a liver carcinogen.Cancer Res. 41: 1253

Choi, E. K. (1989) Suppression of Balb/c mouse splenocyte proliferation and differentiation by protein methylase inhibitors, 5'-isobutyl-5'-deoxyadenosine and sinefungin. Ph. D. Thesis, Wonkwang Univ., Korea

Choi, Y. J., Yonn, S. J., Hong, J. H, Song, W. G., Han, K. I., Cho, T. B. and Paik, M. K. (1992) Studies on S-adenosyl-L-methionine: protein arginyl N-methyltransferase of early human placenta. Korean J. Biochem. 24: 63-70

Doerfler, W. (1983) DNA methylation and gene activity. Annu. Rev. Biochem. 52: 93

Duerre, J. A. and Onisk, D. V. (1985) Specificity of the histone lysine methyltransferase from rat brain chromatin. Biochim. Biophys. Acta 843: 58

Duerre, J. A. (1988) In Advances in Post-translational modification of proteins and aging, (V. Zappia, P., Galletti, R. Porta and F. Wold, eds.), pp. 307-, Plenum

Duerre, J. A., DiMaria, P., Kim, S. and Paik, W. K. (1990) Critical Review in Oncogenensis, pp. 97-108, CRC press

Ghosh, S. K., Paik, W. K. and Kim, S. (1988) Purification and molecular identification of two protein methylases from calf brain. J. Biol. Chem. 263: 19024-19033

Han, K. I. (1994) Purification and characterization of protein methylase I from bovine fetal liver. Ph. D. Dissertation, Wonkwang Univ., Korea

Hoffman, R. M. (1985) Altered methionine metabolism and transmethy-lation in cancer Anticancer Res. 5: 1-

Karn, J., Vidali, G., Boffa, L.. C. and Allfrey, V. G. (1977): Characteri-zation of the non histone nuclear proteins associated with rapidly labeled heterogeneous nuclear RNA J. Biol. Chem. 252: 7307-7322

Kay, R. R. and Johnson, I. R. (1977): Rapid isolation of nuclear envelope from rat liver. In Method in Cell Biology (D. M. Prescott, ed.), Vol. 40, pp 277-, Academic Press, New York

Kaufman S. H., Gibson, W. and Shaper, J. H. (1982) Characterization of major polypeptides of the rat liver nuclear envelope. J. Biol. Chem. 258: 2710-2719

Kumar, A., Williams, K. R. and Szer, W. (1986) Purification and domain structure of core hnRNP protein $\mathrm{A} 1$ and $\mathrm{A} 2$ and their relationship to single-stranded DNA-binding proteins. J. Biol. Chem. 261: 11266-11273

Laemmli, U. K. (1970) Cleavage of structural proteins during the assembly of the head of the bacteriophage T4. Nature 227: 680-685

Lee, H. W. and Paik, W. K. (1972) Histone methylation during hepatic regeneration in rat. Biochim. Biophys. Acta 277: 107-116

Lee, J. Y., Yang, A. S., Hong, J. H., Song, W. G., Han, Y. J. and Paik, M. K. (1994) Nuclear methyl acceptor proteins during hepatic regene-ration in rat. Korean $\mathrm{J}$. Biochem. 26: 157-167

Merrill, B. M., LoPresti, M. S., Stone, K. L.. and Williams, K. R. (1986) High pressure liquid chromatography purification of UP1 and UP2, two related single-strand nucleic acid-binding proteins from calf thymus. J. Biol. Chem. 261: 878-883

Miller, E. C., Miller, J. A., Kline, B. E. and Rush, M. P. (1948) Correlation of the level of hepatic riboflavin with appearance of liver tumor in rats fed aminoazo dyes. J. Exp. Med. 88: 89-94

Najbaur, J. and Aswad, D. (1990) Diversity of methyl acceptor proteins in rat pheochromocytoma( $\mathrm{PC} 12)$ cells revealed after treatment with adeno-sine dialdehyde. J. Biol. Chem. 265: 12717-12721

Paik, M. K., Lee, K. H., Sohn, S. S., Park, I. M., Hong, J. H. and Hwang, B. D. (1991) Human placental protein methylase I. purification and characterization. Intern. J. Biochem. 23: 939-945

Paik, M. K., Yoo, J. H., Hong, J. H., Song, W. G., Kim, J. S., Lim, K. and Hwang, B. D. (1993): Possible role of protein methylation in cellular proliferation and differentiation (I): Characterization of partially purified protein methylase l's from bovine livers and murine splenocytes. Korean J. Biochem. 25: 145-154

Paik, W. K. and Kim, S. (1980) In Protein Methylation, p. 192, John Wiley \& Sons, New York

Paik, W. K. and Kim, S. (1990) Protein Methylation, pp. 23-31, CRC Press, Boca Raton, FL.

Rajpurohit, R., Lee, S. O., Park, J. O., Paik, W. K. and Kim, S. (1994) Enzymatic methylation of recombinant heterogenous nuclear RNP protein A1. J. Biol. Chem. 269: 1075-1082

Reporter, M. and Corbin, J. L. (1971) $N^{G}, N^{G}$-dimethylarginine in myosin during muscle 
Tidwell, T., Allfrey, V. G. and Mirsky, A. E. (1965): The methylation of histones during regeneration of the rat liver.J. Biol. Chem. 243: 707-715

Thomas, J. O. and Kornberg, R. D. (1975) An octamer of histones in chromatin and free in solution. Proc. Natl. Acad. Sci., USA 72: 2626-2630

Tuck, M.T. and Cox, R. (1982) Ethionine causes the formation of $N^{G}$. monomethylarginine in nuclear proteins from regenerating rat liver. Carcinogenesis 3 : 4771

Wainfan, E., Kilkenny, M. and Dizik, M. (1988) Comparison of methyl-transferase activities of pair-fed rats given adequate or methyl-deficient diets. Carcinogenesis 9 : 861-863

Yoon, S. J. (1994) S-Adenosyl-L-methionine: protein arginyl N-methyl-transferase activity during 3'-methyl-4-dimethylaminoazo-benzene-induced hepatocacinogenesis in 